\title{
RESEARCH OF PROFESSIONAL LEGAL CULTURE: METHODOLOGICAL ASPECT
}

\section{Maryna Burdonosova}

\section{INTRODUCTION}

There are radical quantitative and qualitative changes taking place in modern Ukrainian society. In order for legal, political and administrative reforms that are taking place in our country not to "skid", but to realistically influence society and produce a positive result, it is necessary to take into account the level of legal consciousness and legal culture of the social groups to which these radical changes are directed. First of all, there is the question of researching the professional legal culture of lawyers. These categories of persons on a professional basis are called to engage in the implementation of the rules of law. Lawyers must ensure the normative regulation of social activity in accordance with the legal rules and requirements of law.

Revealing the nature of professional legal culture requires the use of the proper scientific instruments capable of guaranteeing adequate and reliable result. The basis of scientific knowledge is rationality preferring not feelings and emotions, it based on logic principles produced and proven over the centuries. It's about principles and methods of research, methodology in general. Each new stage of the progressive development of scientific intelligence is related to the further increasing importance of methodology. The study of issues of professional legal culture depends on the level of development of problems of methodology of research of legal phenomena in the life of society and lawyers, in particular ${ }^{1}$.

The dialectics of any scientific knowledge is expanding and deepening the issue under development causes rethinking and analysis at a new, higher level, baseline data and research background ${ }^{2}$. And the legal field is no exception for such approach of dialectics. Development of the methodology of professional culture can realize a significant contribution to the theory of legal culture and culture in general. Before modern researchers in the field of legal deontology, theory of state and law, legal psychology, legal culture, there are questions of

${ }^{1}$ Kerimov D.A. (2011) Metodologiia prava: Predmet, funktsii, problemy filosofii prava [Methodology of law: Subject, functions, problems of legal philosophy] (6th ed.). Moscow: Publishing House of the SGU, pp. 60-61. (in Russian).

${ }^{2}$ Sokolov N.Ya. (2014) Professionalnaia kultura yuristov. Poniatie. Sushchnost. Soderzhanie [Lawyers professional culture. Concept. Essence. Contents]. Moscow: Prospect, p. 52 (in Russian). 
complex analysis of the relationship between legal knowledge, legal awareness, legal action and implementation of law.

The purpose of this disquisition is scientific and theoretical analysis of methodological issues of research of the professional legal culture of lawyers. This is done by identifying the following tasks: - identify the specifics of the methodology of the study of legal culture; - to identify methodological features of research of the professional culture of lawyers; - to formulate particular qualities of using some methods of study of professional legal culture.

Various aspects of the study of professional legal culture have been considered in legal literature by such scientists as: Anufrienko O.A., Bezborodyi V.O., Vengerov A.B., Groshevyi Yu.M., Ilyin I.O., Kozyubra M.I., Kotiuk V.O., Onishchenko N.M., Orzikh M.V, Sokolov M.Ya., Slivka S.S. and others.

The methodology of law was analysed by such scientists as: Alekseev S.S., Baranov V.M., Bandura O.O., Bryzgalov A.I., Gusarev S.D., Kazimirchuk V.P., Kerimov D.A., Kresin O.V., Krizhanovsky A.F., Lapayeva V.V., Oborotov Y.M., Pershin V.B., Polyakov A.V., Rabinovych P.M., Radko T.M., Selivanov V.M., Serdyuk O.V., Syrykh V.M., Skakun O.F., Tarasov M.M., Tykhomyrov O.D. and others.

Despite the significant contribution of these and other scholars to the development of the methodological foundations of law and the professional culture of lawyers, it would be fair to emphasize that the question of their combination remained. Not sufficiently disclosed the analysis of methodological approaches to the study of professional legal culture and identification of their peculiarities in order to identify the most effective methods of comprehensive approach for new scientific advances in this direction.

\section{Methodological features of study of professional legal culture}

The importance of analysing methodological issues is related to the fact of increased role of law in the process of building a democratic, social, legal civil society. This formation places greater demands on the justification of basic methodological positions of scientific knowledge by legal scholars.

The modern stage of science progress is characterized by intense development of methodology problems, which characterizes all branches of scientific knowledge. Such intensity is explained first of all by needs of deeper and comprehensive knowledge of the complex processes of social life and prospects for its development. Interesting in this aspect is the thought of modern scientists that in our time in the legal science has developed a situation where the political and legal phenomena of the past could be 
adequately understood with the help of fundamentally new to legal science scientific methods ${ }^{3}$. Development of the methodology of professional legal culture will be able to make a significant contribution to the theory of legal culture. This, in turn, is the main structural unit of the general theory of state and law. In addition, modern legal science developed new techniques and methods of research, requires a clearer organization of the activities of legal scholars in order to effectively use the data they received in practice.

Such problems of the modern Ukrainian society as enhancing the legal culture of the society, reducing the level of legal nihilism, are simultaneously investigated by several separate scientists, independently of each other. However, it would be more appropriate to create a dedicated team of scientists who would concentrate their efforts to solve the problem promptly and effectively. The obstacle to the implementation of such interaction and communication between scientific lawyers is the lack of methodological developments in this area, as well as some doubts about in professional honesty of scientists and virtue of possible colleagues (fear of losing the results of the research or their assignment to third parties). It points on existence of certain limitations in the professional legal culture.

Furthermore, coordination and engagement in solving social and legal life problems acquires great importance. Contemporary Ukrainian reality sets new tasks before the science. And there is an objective need for the participation of legal scholar's teams in solving the problems of legal practice. First of all, it is relevant in solving the following issues: improvement of legislation; law enforcement activities; strengthening the rule of law in the state; formation of law and order; raising the level of legal culture of citizens. The demand to enhance the self-analysis of legal science is caused not only by the need to develop the theory itself, but also by the need to improve legal practice.

New scientific developments that affect practice put increased demands on the responsibility of legal scholars. Science must guarantee reliability of such recommendations. Therefore, the support of the prestige of legal science depends to a large extent on the objectivity of its judgments, providing guarantees of the reliability of scientific conclusions. In this regard, it is necessary to agree with Sokolov M., who argues that an important contribution of legal science in practice can be made by studying the laws and features of the formation of professional

${ }^{3}$ Chernetska O.V., Shilingov V.S. (2009) Yurydychna komparatyvistyka yak samostiyna yurydychna naukova dystsyplina [Legal comparative studies as an independent legal scientific discipline]. Ukrainian Greek International Scientific Law Journal "Comparative Legal Studies", 2009, vol. 1, p. 26. (in Ukrainian). 
legal culture of different categories of legal practitioners. Professional legal culture development will prevent possible deformation of legal consciousness and legal nihilism ${ }^{4}$.

Another reason for the appeal to the issues of methodology of legal science is essential to enrich it with new tools of research, the increasing involvement of funds, which were previously used by such sciences as mathematical logic and information theory. In particular, widespread among legal scholars method of sociological research, use of computer technology and Internet requires clarification of conditions for their adaptation in the field of law and influence legal science. Immediate accumulation scientific knowledge must be accompanied by knowledge of the science of special theoretical principles and methods of analysis. New knowledge should be evaluated not only the classical methodological tools, but also should facilitate the search for new approaches to their study ("new to new") that meet the needs of modern society. Legal science can solve new practical problems that arise exactly in our society.

One of such important social "orders" for legal scholars is to create a social-psychological portrait of a modern lawyer. In the existing scientific researches, the legal culture of specific professional groups, such as judges, prosecutors, police officers, heads of internal affairs bodies, has been considered to a greater extent. In support of this, more general philosophical and legal studies in this area have been initiated ${ }^{5}$. It should be noted that the issues of elucidation of the general laws of formation and development of professional legal culture of modern lawyers remain insufficiently covered. That's why it requires the development of the methodological component of such research.

Besides, it should be considered that the problem of professional legal culture has dual nature. The study of the professional culture of lawyers should take into account dual legal categories and concepts. In addition, the scientific apparatus includes the legal concepts of "right", "law", "duty", "responsibility", "social and legal order", "justice". It is necessary to apply also cultural, sociological, psychological concepts and categories, such as

\footnotetext{
${ }^{4}$ Sokolov N.Ya. (2014) Professionalnaia kultura yuristov. Poniatie. Sushchnost. Soderzhanie [Lawyers professional culture. Concept. Essence. Contents]. Moscow: Prospect, p. 54 (in Russian).

${ }^{5}$ Slivka S.S. (2002) Filosofsko-pravovi problemy profesiinoi kultury yurysta [Philosophical and legal issues of professional culture of lawyers]. (PhD Thesis), Kharkiv: National Yaroslav the Wise Law Academy of Ukraine, pp. 4, 9-11.

Chuprinsky B.O. (2010). Formuvannia profesiinoi kultury maibutnih yurystiv: filosofskopravove doslidzhennia [Formation of professional culture of future lawyers: philosophical and legal research]. Extended abstract of candidate's thesis. Lviv: Lviv State University of Internal Affairs, pp. 5, 9. (in Ukrainian).
} 
"values", "traditions", "social group", "activity" and "behaviour". So we can argue that this phenomenon is an integrative idea, which is located on the cutting edge of legal science, cultural studies, sociology, and psychology. Enumerated science from different points of research analyse the issues of legal consciousness of those who must defend the law in society.

Considering dual nature and interdisciplinar peculiarity, the most appropriate methodological construction of the legal culture study is as follows: 1) based on the laws and categories of dialectics, 2) using general scientific methods of legal science, 3) take as a basis the theoretical and legal categories, ideas, concepts of the laws of legal science and special scientific methods, 4) apply cultural studies, sociological, psychological concepts and categories.

The professional legal culture of lawyers is a complex concept and is interdisciplinary. In order to fully explore such phenomena it is necessary to use achievements of sciences:

- Sociology (concepts as social groups and subjects), since we reserch specific social group - lawyers, subjects united by a single profession;

- Cultural studies, namely, the concept of traditional values of a particular society, wich lawyers must protect;

- Psychology in particular, concept of activity and behaviour, which is the basis for distinguishing between legal and illegal actions and criminal behaviour;

- Jurisprudence, namely with the correlation of right and law, which is the basis of legal culture.

The interdisciplinary nature of the study of professional legal culture causes the emergence of special phenomena that arise at the intersection of the indicated areas. Therefore, to assess the level of such culture among lawyers, resercher should consider the presence of such qualities as:

- Sense of social justice and an awareness of the need to protect it as a representative of a profession based on this principle, Lady Justice (from latin: Iustitia) is an allegorical personification of the moral force in judicial systems;

- Internal responsibility for their actions and decisions combined with a sense of professional duty;

- Level of development of legal consciousness;

- Understanding the value of the legal order, ensuring the conflict-free existence of society (scheme 1).

\footnotetext{
${ }^{6}$ Burdonosova M.A. (2015) Metodolohichni osoblyvosti doslidzhennya profesiynoyi kultury yurystiv [Methodologocal features of reserch of professional culture of lawyers]. Public law, vol. 4(20)/2015, pp. 261-266. (in Ukrainian).
} 


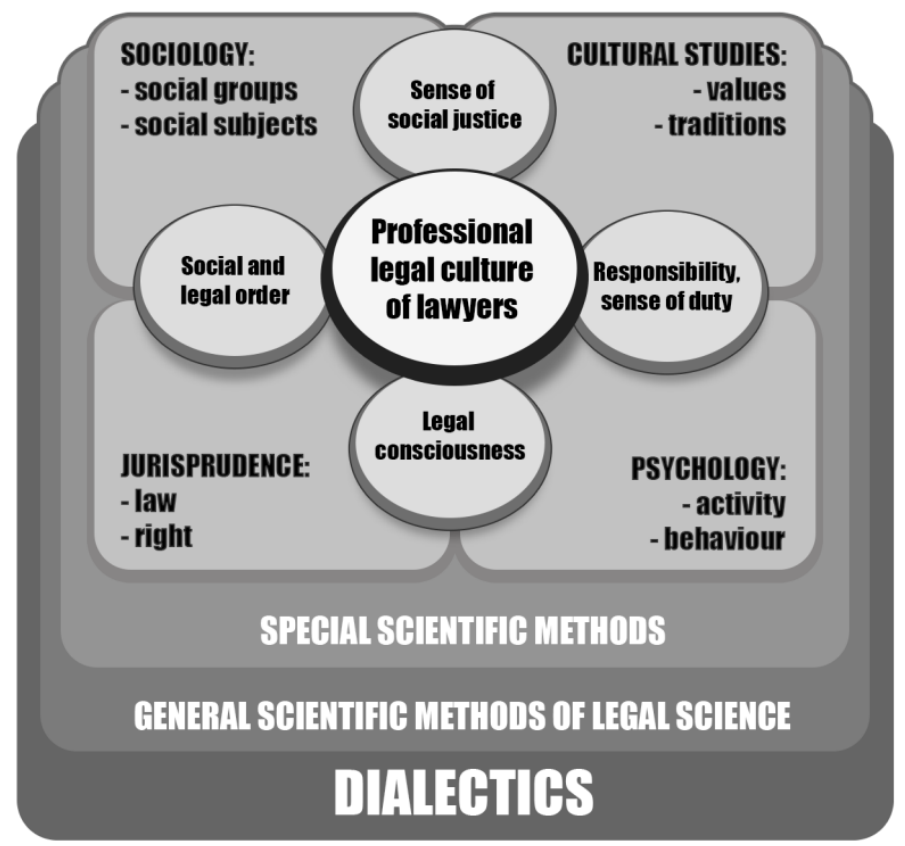

\section{Scheme. 1. Methodological construction of study of the professional legal culture of lawyers}

The problem of synthesis of legal and cultural concepts needs special attention of the researcher, as wel as their combination into united complex. Also, it would be advisable to apply a comprehensive, integrative approach to the study of the professional culture of lawyers. Taking this ratio into account will prevent unnecessary legitimization of the results of the study and at the same time avoid significant distortions towards cultural studies or psychology.

According to systematic approach the methodology of scientific knowledge is a system of different levels based on common methods of thinking (analysis, synthesis, abstraction, generalization, induction, deduction, analogy and modeling) ${ }^{7}$. And also, agreeing with Kazimirchuk V.P., that methodology of legal science is the application of a system of logical

${ }^{7}$ Yudin E.G. (1978) Sistemnyi podhod i printsip deiatelnosti. Metodologicheskie problem sovremennoi nauki [Systematic approach and the principle of action. Methodological problems of modern science]. Moscow: Nauka, pp. 41-44 (in Russian).

Gusarev S.D., Tykhomyrov O.D. (2010) Yurydychna deontologiia (Osnovy yurydychnoi diialnosti) [Legal deontology (Principles of Law): teach. guidances.] (4th ed.). Kyiv: Znannia, pp. 73-91 (in Ukrainian). 
techniques, special methods and methods of study of legal phenomena, which are determined by the theoretical principles of materialistic dialectics ${ }^{8}$. We can define the methodology for the study of the professional culture of lawyers, as, based on common methods of thinking, system of logical techniques, principles and methods of organization, construction and implementation of theoretical and cognitive activity in the field of professional legal culture research of various groups of lawyers.

It seems that the application of logical techniques, special methods and methods for the study of professional legal culture, which are determined by the theoretical principles of dialectics, will clarify the essence of the methodology of this phenomenon and reveal its vertical construction. Conducting research on specific types directs the researcher to the depth of horizontal construction of the system:

- At the level of philosophical methods, it is advisable to rely on the laws and categories of materialistic dialectics;

- At the level of general scientific methods - to apply systemic, synergistic, behavioral, structural, functional, method of comparison and modeling for legal "field";

- At the level of special scientific methods - to use interview, questioning and analysis of the answers of the professional-legal group, observation of the professional activity of lawyers, comparative, statistical, method of mathematical processing of results;

- At the level of specialized scientific methods - to work out the results of psychological methods of personality studying, different influences on it and checking the mental qualities of the lawyer's personality.

\section{Particular qualities of using some methods of study of professional legal culture}

Methods of researching the legal culture of lawyers are part of the methods of legal science. However researchers still need to study methods for solving a particular legal problem. A similar approach extends to the study of the diverse phenomena of professional legal culture.

The techniques of studying of professional legal culture include:

- Analysis of statistical data, official communications and documents, scientific literature, press appearances, radio and television, related to professional and legal activities;

${ }^{8}$ Kazimirchuk V.P. (1965) Pravo i metody ego izucheniia [Law and methods of its study [monograph]. Moscow: Yurydychna literatura, p. 44 (in Russian). 
- Methods of analysis of work of lawyers: observation, method of analysis of critical situations;

- Survey and analysis of group professional legal opinion;

- Psychological (social-psychological) methods;

- Interview and written surveys (questionnaires);

- Methods of mathematical processing.

Researching of legal culture of lawyers also involves two main ways. The first is related to the artificial isolation by the researcher some individual phenomenon of professional legal culture. For example, this is used in a laboratory experiment or simulation.

The second way is a "field research". Where the "field" is the natural space where the activity of the individual unfolds. The researcher's task is to organize the study with minimal influence on the natural conditions. Due to the specific nature of legal activity, compliance with this requirement is of fundamental importance. The influence of the researcher on the decision of legal workers of criminal and civil cases is inadmissible. This means that the principle of legality extends to the field of scientific study of professional legal culture.

1. Comparative method. This method is not just a certain system of thinking, that is, the sum of the criteria that must ensure that the right one is achieved result, but it is also a working method. Comparison in law is relatively independent, systematically organized a way of research in which comparison is necessary to achieve specific goals of cognition. A relatively legal study by comparisons systems discover the common and also finding out what different. Both tasks and opportunities are relatively legal research (establishing common and different in comparable objects) are also interconnected, both common and distinct in legal systems.

On the one hand, comparison involves establishing a commonality that can be detected only by the comparative method, and on the other - helps to distinguish between the compared objects. The comparative legal method is one of the important means of study legal phenomena. Thanks to its application it becomes possible to detect for general, particular and specific in the legal systems of the present day.

Criteria for comparative legal research should be considered in more detail. In this regard, it is important to identify decussate theories through which one can find the institutions and norms that belong to different legal systems, and they are so comparable, that this comparison is justified. The point of departure here is to use the same concepts and terms used in another legal system, and this has the effect of comparing related systems. Expanding the area for compared legal phenomena increases the risk of 
errors in process of searching for a foreign term that would correspond to the domestic one'.

Heterogeneous legal culture as well as the same type of professional legal culture can be the object of the comparative method. It can be applied not only to two or more legal systems or their structural components. We can use this method when organizing a comparative study of the professional culture of lawyers of various countries belonging to the European Union. This is relevant for the process of implementing European legal experience in the legal system of Ukraine.

At the same time, a comparative study of of professional culture of various groups of legal workers: judges, prosecutors, lawyers, notaries, legal advisers, police officers are of particular importance for increasing the level of their legal consciousness. Some components of a professional culture are difficult to determine without using a comparison method, for example, mutual evaluations of each other by different categories of legal workers. A comparison of professional legal culture allows more accurately establish its condition and develops scientific recommendations for practical legal institutions and bodies.

2. Systematic approach allows studying structure, functions, development of professional legal culture. It has cognitive capabilities, as well as the lack of use by legal scholars. The works in the legal literature, despite their great importance and deep theoretical content, can only be recognized as the beginning of a comprehensive study of legal phenomena.

Before using a systematic approach in the study of a particular legal object, it is necessary to estimate the possibility of considering the research object as a holistic system. System concepts are used very widely, sometimes even where they should not be used, where the application of a systematic approach is not dictated by scientific or practical necessity. That is why the consideration of a professional legal culture as a system should be justified by the choice of such an approach. Research on legal consciousness and legal culture is no exception. The issues of structure are given considerable importance. However, not always these studies in the full sense can be recognized as systemic. The notion of structure is used by their authors in a very broad sense, as a collection of elements and relationships. This resultis that the concept of structure identified with the concept of the whole. But more productive understanding of structure, in the narrow sense, as the

${ }^{9}$ Chernetska O.V., Shilingov V.S. (2009) Yurydychna komparatyvistyka yak samostiyna yurydychna naukova dystsyplina [Legal comparative studies as an independent legal scientific discipline]. Ukrainian Greek International Scientific Law Journal "Comparative Legal Studies", 2009, vol. 1, p. 27. (in Ukrainian). 
interconnecting and interacting parts of the whole. In the literature on the problems of the theory of legal culture, insufficient attention is paid to the analysis of the functional relations of the system of legal culture, the interaction of functions and structural elements, connection of legal cultural studies with practice.

Systematic approach allows combining analysis and synthesis, qualitative and quantitative in the study of social processes. This opens up great opportunities for the application of heuristic and logic-mathematical methods.

Professional legal culture can be considered as a relatively independent holistic system. It matches the requirements for holistic systems that are formulated in philosophical, cultural, sociological and legal sciences in the process of developing systemic problems in society, the state and law. An important result of these studies is the conclusion that systematicity is a universal attribute of matter and consciousness, but integrity is a specific property. Not all phenomena of reality have such specific property as systematicity.

The systematic nature of professional legal culture is the result of the systematic nature of the world around us, which acts as their inherent property. The legal culture, including professional, is systemic, since they reflect the legal reality. The systemic nature of legal reality naturally determines the systemic nature of the consciousness and culture reflecting and cognizing it, including professional level.

As noted by Sokolov N.Ya., professional legal culture matches all the requirements for holistic systems. These include: integrativity; the presence of the necessary connections between elements, components and the system; structurality (organization); purpose and expediency; functioning; control; development ${ }^{10}$.

The significance of a systematic approach to the study of professional legal culture is largely determined by the inextricable link of legal activity with management. In this area, such an approach was most developed and brought noticeable practical results. Research in this direction will further enhance the level of legal culture of legal personnel. The study of the system of professional legal culture can help improve the ways, means, methods and forms of increasing its level.

3. Statistical method studies the quantitative aspect of changes in the social life, processes the obtained results for the scientific and practical purposes of establishing and studying the quantitative characteristics of the

${ }^{10}$ Sokolov N.Ya. (2014) Professionalnaia kultura yuristov. Poniatie. Sushchnost. Soderzhanie [Lawyers professional culture. Concept. Essence. Contents]. Moscow: Prospect, 320 p. (in Russian). 
state-legal phenomena. Statistical surveys (for example, the number of normative acts regulating a particular relationship, the number of unsolved crimes) reveal some trends in the development of public relations.

Statistical method is one of the most powerful tools of social cognition. Social science cannot be based on random single data; the laws of the phenomena studied by it can be established only with mass statistical research. Statistical patterns are manifested in mass social processes, in aggregates of social objects consisting of a large number of units. They are formed in accordance with the law of large numbers. The simultaneous influence of a large number of random factors and causes leads to results that are almost independent of the case.

The law of large numbers is one of the basic laws used by statistics to study the phenomena of public life. It allows us to understand why, due to the large amount of random communication chaos, we can establish patterns in the development and trends of social phenomena. One or even a small number of cases in social life can give random, non-peculiar, overall indicators (for example, recidivists are usually people with low educational attainment, but some individuals with higher education may be identified).

Therefore, in the study of social phenomena, it is necessary to make mass observations, based on the law of large numbers. Otherwise, the conclusions drawn from a small number of facts can be misleading. Mass registration of facts and their research allow us to reject the accident, which may be inherent in individual manifestations and to determine the regularity contained in the totality of phenomena.

Statistical patterns express causal relationships that exist in the area of social phenomena and processes. Statistical patterns are also manifested in the field of professional legal activity, which allows us to make conclusions about the state of the professional culture of lawyers and identify factors that have a significant impact on it.

Material for the study of professional consciousness is provided by legal statistics characterizing the activities of various legal bodies and institutions for combating crime, statistical reports on the composition and movement of personnel of employees of the judiciary, court, prosecutor's office, etc. The same way data of criminal law and civil law statistics can be used to study professional legal culture.

The statistical method provides comprehensive, scientifically justified information on trends and patterns in crime development. The level of crime, the structure, the identity of the offender, the causes and conditions of the existence of crime, as well as the positive and negative consequences of the work of law enforcement agencies on its prevention can be studied on the basis of statistics. 
The statistical method plays a significant role in the legal process of coordinating the activities of different law enforcement agencies in order to overcome their fragmentation. Systematic study and use of legal statistics is necessary in order to increase the level of professional legal culture, improve personnel work in legal bodies. For example, the study of the causes of judicial errors will increase the efficiency of the judicial authorities, including the level reduction of offenses, participation in the legal education of citizens.

4. Modeling method is based on the theory of similarity. It is based on the assumption that one-to-one correspondences can be established between different objects; therefore, knowing the characteristics of one, resercher can to establish the other. The object, by monitoring which you can get an idea of another object, is called a model, and the research process based on this correspondence is called modeling.

In the modeling process, an analogue of the object under study is created, in our case, professional legal culture, or its components. Phenomens correlates of on the basis of "cause - effect". Modeling allows you to create informative situations, and not just wait for their occurrence. It is associated with the process, dynamics, development and search. Due to the ability of modeling to provide a compact organization of facts, it is able to more clearly demonstrate their relationship, which is not always possible in the process of establishing and describing them. The modeling method also has a significant prospect in the study of professional legal culture in the sense that it allows more widespread involvement of quantitative data into the analysis, the use of the mathematical apparatus, and the introduction of new variables ${ }^{11}$.

Before starting the modeling of the problem, an understanding of the structure of the object or its elements is necessary. If the structure of professional legal culture is defined, then the purpose of modeling is its functioning in different conditions. If the researcher of professional legal culture has information about the individual elements and functions of an object, then the purpose of modeling is its structure.

Modeling of professional legal culture corresponds to those tasks which are usually set before it. It is functionally essential to practice. Accordingly, the work of the model has a direct influence on practice. In the legal literature, it is correctly noted that one of the main advantages of this method is that it allows you to "simulate the activities of people involved in law, especially lawyers, in such important areas of public life as management, law-making,

${ }^{11}$ Brudnyi A.A. (1977) K probleme modelirovaniya v sotsialnoy psikhologii [To the problem of modeling in social psychology]. Metodologiya i metody sotsialnoy psikhologii. [Methodology and methods of social psychology]. Moscow: Nauka, pp. 86-95 (in Russian). 
and the administration of justice. It is of great importance for the use of cybernetic machines in law" 12 .

By analyzing the effect of the model, it is possible to find previously unknown structural and functional features of the object of modeling - the existing legal culture. In the course of the study of professional legal culture conducted by Sokolov, the significance of the stereotype of the criminal in the professional activities of a lawyer was established. It helps to determine in a preliminary, schematic form a plan for a possible solution to a particular case. Thus, when the model is correct and correctly reproduces the object under study, the researcher can move from it to the model, which begins to temporarily replace the object ${ }^{13}$.

With all the advantages of the modeling method, it has several disadvantages. Model-schemes have limited possibilities for influencing cognitive activity. Schemes alone cannot prove results; they can only illustrate the process if its individual elements are clarified theoretically.

Modeling, especially when the model has proved its efficiency, allows us to plan and conduct new observations and studies. For example, the model of the structure of professional legal culture is constant for studying the legal social and professional group as a whole. After making clarifying adjustments to it, it can be used to study the professional culture of different groups of legal workers.

\section{CONCLUSIONS}

One of important social "order" for legal scientists is to create social and psychological portrait of the modern lawyer. Enough questions remain illuminated clarify the general laws of formation and development of modern legal culture of professional lawyers, which in turn requires the development of methodological part of the study.

It should be considered that the problem of professional legal culture has dual nature. The study of the professional culture of lawyers should take into account dual legal categories and concepts. In addition to the fact that the scientific apparatus includes the legal concepts of "right", "law", "duty", "responsibility", " social and legal order", "justice". It is necessary to apply also cultural, sociological, psychological concepts and categories, such as "values", "traditions", "social group", "activity" and "behaviour".

${ }^{12}$ Kazimirchuk V.P. (1965) Pravo i metody ego izucheniia [Law and methods of its study [monograph]. Moscow: Yurydychna literatura, P. 163 (in Russian).

${ }^{13}$ Sokolov N.Ya. (2014) Professionalnaia kultura yuristov. Poniatie. Sushchnost. Soderzhanie [Lawyers professional culture. Concept. Essence. Contents]. Moscow: Prospect, P. 68. (in Russian). 
Considering dual nature and interdisciplinar peculiarity, the most appropriate methodological construction of the study of legal culture is as follows: - based on the laws and categories of dialectic; - using general scientific methods of legal science; - take as a basis the theoretical and legal categories, ideas, concepts of the laws of legal science; - apply cultural studies, sociological, psychological concepts and categories.

Profesional legal culture of lawyers is an integrative idea, which is located on the cutting edge of legal science, cultural studies, sociology, and psychology. Enumerated science from different points of research analyse the issues of legal consciousness of those who must defend the law in society. Methodology of the research of culture of professional lawyers is - based on the general methods of thinking, logical system techniques, principles and methods of organization, construction and implementation of epistemological research activities in the field of professional legal culture of various groups of lawyers who are involved in different areas of society.

Comparative study of of professional culture of various groups of legal workers: judges, prosecutors, lawyers, notaries, legal advisers, police officers are of particular importance for increasing the level of their legal consciousness. A comparison of professional legal culture allows more accurately establish its condition and develops scientific recommendations for practical legal institutions and bodies.

The significance of a systematic approach to the study of professional legal culture is largely determined by the inextricable link of legal activity with management. Research in this direction will further enhance the level of legal culture of legal personnel. The study of the system of professional legal culture can help improve the ways, means, methods and forms of increasing its level.

The statistical method plays a significant role in the legal process of coordinating the activities of different law enforcement agencies in order to overcome their fragmentation. Systematic study and use of legal statistics is necessary in order to increase the level of professional legal culture, improve personnel work in legal bodies.

Modeling of professional legal culture corresponds to those tasks which are usually set from practice. The main advantages of this method is that it allows to simulate the activities of people involved in law, especially lawyers, in such important areas of public life as management, law-making, and the administration of justice.

\section{SUMMARY}

The theoretical analysis of methodological questions of research of professional culture of lawyers is conducted in the reserch. For this purpose 
the specific of methodology is outlined and the methodological features of research of professional culture of lawyers are determined. Special methodological construction is offered for such research.

Development of the methodology of professional legal culture will be able to make a significant contribution to the theory of legal culture. This, in turn, is the main structural unit of the general theory of state and law. In addition, modern legal science developed new techniques and methods of research, requires a clearer organization of the activities of legal scholars in order to effectively use the data they received in practice.

Author defines the following problems: identify the specific research methodology of legal culture; identify methodological features of studies professional culture of lawyers; identify particular qualities of using such methods of study of professional legal culture as: comparative, systematic, statistical, modeling. On the basis systematic approach author defines understanding of methodology of research of professional culture of lawyers.

\section{REFERENCES}

1. Kerimov D.A. (2011) Metodologiia prava: Predmet, funktsii, problemy filosofii prava [Methodology of law: Subject, functions, problems of legal philosophy] (6th ed.). Moscow: Publishing House of the SGU, $521 \mathrm{p}$. (in Russian).

2. Sokolov N.Ya. (2014) Professionalnaia kultura yuristov. Poniatie. Sushchnost. Soderzhanie [Lawyers professional culture. Concept. Essence. Contents]. Moscow: Prospect, 320 p. (in Russian).

3. Slivka S.S. (2002) Filosofsko-pravovi problemy profesiinoi kultury yurysta [Philosophical and legal issues of professional culture of lawyers]. (PhD Thesis), Kharkiv: National Yaroslav the Wise Law Academy of Ukraine, $32 \mathrm{p}$.

4. Chuprinsky B.O. (2010) Formuvannia profesiinoi kultury maibutnih yurystiv: filosofsko-pravove doslidzhennia [Formation of professional culture of future lawyers: philosophical and legal research]. Extended abstract of candidate's thesis. Lviv: Lviv State University of Internal Affairs, 20 p. (in Ukrainian).

5. Burdonosova M.A. (2015) Metodolohichni osoblyvosti doslidzhennya profesiynoyi kultury yurystiv [Methodologocal features of reserch of professional culture of lawyers]. Public law, vol. 4(20)/2015, pp. 261-266. (in Ukrainian).

6. Yudin E.G. (1978) Sistemnyi podhod $i$ printsip deiatelnosti. Metodologicheskie problem sovremennoi nauki [Systematic approach and the principle of action. Methodological problems of modern science]. Moscow: Nauka, 378 p. (in Russian). 
7. Gusarev S.D., Tykhomyrov O.D. (2010) Yurydychna deontologiia (Osnovy yurydychnoi diialnosti) [Legal deontology (Principles of Law): teach. guidances.] (4th ed.). Kyiv: Znannia, 495 p. (in Ukrainian).

8. Kazimirchuk V.P. (1965) Pravo i metody ego izucheniia [Law and methods of its study [monograph]. Moscow: Yurydychna literatura, $204 \mathrm{p}$. (in Russian).

9. Chernetska O.V., Shilingov V.S. (2009) Yurydychna komparatyvistyka yak samostiyna yurydychna naukova dystsyplina [Legal comparative studies as an independent legal scientific discipline]. Ukrainian Greek International Scientific Law Journal "Comparative Legal Studies", 2009, vol. 1, pp. 23-28. (in Ukrainian).

10. Brudnyi A.A. (1977) $\mathrm{K}$ probleme modelirovaniya $\mathrm{v}$ sotsialnoy psikhologii [To the problem of modeling in social psychology]. Metodologiya $i$ metody sotsialnoy psikhologii. [Methodology and methods of social psychology]. Moscow: Nauka, pp. 86-95 (in Russian).

\section{Information about the author: \\ Maryna Burdonosova,}

$\mathrm{PhD}$ in Law,

Associate Professor at the Department of Constitutional and Administrative Law, Faculty of Law, Institute of Management and Technology, State University of Infrastructure and Technologies 2, Heroiv of Stalinhradu Ave, Kyiv, Ukraine ORCID ID: orcid.org/0000-0003-1050-6892 